\title{
In English or into English? Prepositional and Particle Usage in Translated Discourse
}

\author{
¿En inglés o hacia el inglés? El uso de preposiciones y partículas en el discurso traducido \\ Em inglês ou para o inglês? 0 uso de preposições e partículas no discurso traduzido
}

Elena Rodríguez-Murphy* (https://orcid.org/0000-0002-0595-5709)

Department of Translation and Interpreting, University of Salamanca, Salamanca, Spain.
Received: 22-04-17

Revised: $14-09-17$

Accepted: $10-10-17$

Published: 06-11-17

\begin{abstract}
On carrying out diagnostic assessment of the different levels of “interlanguage" (Selinker, 1972) of translator trainees at the University of Salamanca, who use their working languages-in this case English-at near-native level when practising inverse translation, the writer has been able to observe that one of the areas in which even the most proficient students are likely to find certain difficulty is that of prepositional "usage" and "use" (Widdowson, 1978). When dealing with the interpretation and translation of prepositions and particles in a wide range of structures and contexts, knowledge of both their usage and a feeling for their use is essential if the often important nuances which they express in combination with other linguistic elements are not to be forfeited. The principal aim of this article is to underline this notion, contributing both samples of prepositional and particle usage in translation and relevant observations for promoting the in-class development of an awareness of the problems encountered concerning the comprehension of the source text and its subsequent re-expression.
\end{abstract}

Key words: translation,

training,

English,

Spanish,

prepositions

RESUMEN. Al llevar a cabo un análisis diagnóstico de los diferentes niveles de “interlengua" (Selinker, 1972) característicos de los estudiantes de traducción de la Universidad de Salamanca que, al realizar traducciones a la inversa, utilizan sus

Palabras clave: traducción, formación,

Cite as: Rodríguez-Murphy, E. (2017). ¿En inglés o hacia el inglés? El uso de preposiciones y partículas en el discurso traducido. Revista Digital de Investigación en Docencia Universitaria, 11(2), 155-168. doi: http://dx.doi.org/10.19083/ridu.11.535

*E-mail: er.murphy@usal.es 
lenguas de trabajo, en este caso el inglés, a nivel prácticamente nativo, se ha podido observar que una de las cuestiones que supone gran dificultad, incluso para los estudiantes más avanzados, suele ser el uso de preposiciones (Widdowson, 1978).

inglés, español, preposiciones Al enfrentarse a la interpretación y traducción de preposiciones y partículas en una amplia variedad de estructuras y contextos, resulta fundamental tener un conocimiento de su uso lingüístico y pragmático si se quieren transmitir los importantes matices que habitualmente encierran. El objetivo principal de este artículo es subrayar este aspecto y proponer diversos ejemplos traducidos y observaciones relevantes que permitan resaltar en clase las dificultades inherentes tanto a la comprensión del texto fuente como a su posterior traducción.

RESUMO. Uma análise diagnóstico dos diferentes níveis de interlíngua (Selinker, 1972) em estudantes de tradução da Universidade de Salamanca detectou que quando eles utilizavam suas línguas de trabalho em traduções inversas, no caso o inglês no nível Avançado, uma das áreas de maior dificuldade foi a do uso das preposições, tanto no plano linguístico quanto no comunicativo pragmático (Widdowson, 1978). A tradução e interpretação de preposições em um amplo leque de estruturas e contextos supõe, essencialmente, o conhecimento da norma culta e do uso pragmático de tais partículas, assim como das nuances que elas expressam quando combinadas com outros elementos linguísticos. O objetivo principal deste artigo é destacar este conceito e contribuir com uma amostra do uso de preposições, assim como oferecer observações pertinentes para sublinhar os problemas encontrados na compreensão do texto de origem e sua tradução posterior.

On carrying out diagnostic assessment of the different levels of "interlanguage" (Selinker, 1972) of translator trainees, who use their working languages-in this case English-at a near-native level when practising inverse translation, the author has regularly had occasion to observe that one of the areas in which even the most proficient students are likely to find difficulty is, from a formal linguistic perspective, that of prepositional "usage" and, from a communicative perspective, prepositional "use" (Widdowson, 1978). In undergraduate and postgraduate language and translation classes (in the Spanish-English combination) at C1-C2 levels of the CEFR (Common European Framework of Reference for Languages) of the Translation and Interpreting degree courses at the University of Salamanca, the author has also observed that there is a tendency toward this kind of difficulty in all cases, although certain recurrent errors in the choice of preposition or particle-often due to language transfer or cross-linguistic influence (Liming \& Odlin, 2015; Odlin,2010)-are sometimes characteristic of particular nationality groups, and not necessarily of others. This would, therefore, seem to imply that at least some of the errors detected are the result of literal translation techniques based on false analogies established between the use 
of certain prepositions in the students' mother tongue which are mistakenly seen as equivalents of prepositions and particles in English. As Swan (1995) pointed out in his Practical English Usage, the English preposition "at" has been documented as having eighteen main uses or functions (p. 444), so it is easy to comprehend why during their learning process, EFL users, in general, would be wise not to make assumptions about possible equivalents, based on a one-to-one relationship, for this type of linguistic form in their own language. Interestingly, such lexico-grammatical choices are typically not a reflection of the kinds of mistakes or slip-ups that a native speaker makes. As Corder (1973) asserts:

Native speakers, then, make slips or false starts or confusions of structure. I shall call these all lapses. They much more rarely commit breaches of code, or errors. Both these sorts of mistake produce unacceptable utterances .... Whilst learners of a language are certainly liable to lapses and mistakes of the sort I have described, the great majority of their errors are of a different kind ... the sign of an imperfect knowledge of the code. The learners have not yet internalized the formation rules of the second language (p. 259).

Corder (1973) also underlines the fact that lapses made by native speakers are usually selfcorrected, whereas the foreign language learner is often not aware of recurrent errors that need to be remedied; typical examples in EFL are "they will arrive to the hotel early before attending to the conference," where "arrive to" shows a wrong choice of preposition in a combination which sounds odd but is, nevertheless, easy to comprehend, unlike "attend to" where the preposition is unnecessary and lends a different meaning to the verb, i.e., preparing or paying attention to. In these instances, the guiding role of EFL teachers and their skill in preparing appropriate materials and tasks conducive to analysis, discussion, and practice are fundamental (Beeby, 1996). "The real learning of theory, even for the self-learner, should be in dialogue and debate"; this observation, made by Pym (2010, p. 5) in his book Exploring Translation Theories, could be re-applied in the context of in-class enquiry, exploration, and debate centred on the types of samples presented in this article.

Naturally, students should be regularly exposed to texts which are linguistically correct, cohesive and coherent, but as an aid to reflection on the challenges and importance of conscientious translation, a presentation of samples of negative instances for discussion and analysis, with their own or others' errors, can be a step on the way to correcting fossilised errors shared by a group or embedded in their individual level of interlanguage. In other words, when errors that impede adequate communication do occur, they should be pointed out and explored, but always from the perspective of encouraging students to enquire and question the appropriateness of certain linguistic forms in favour of others when re-expressing messages conveyed in a source text.

Fortunately, much has been written in the last few decades about the role of cohesion and coherence in achieving successful communication in any kind of speech act, written or spoken, yet, within the "unified whole" (Halliday \& Hasan, 1976, p. 1) of any piece of discourse, structural linguistic accuracy also necessarily comes into play. In the words of Cook: "Discourse and formal skills are interdependent and must be developed together" (1989, p. 79). An inappropriate selection of linguistic forms, such as prepositions or particles, can lead not only to an impression of peculiarity because it does not fulfil the linguistic expectations of the receiver of a message, but more seriously to misrepresentation on the part of the sender or of the translator as intermediary or rewriter, and misunderstanding on the part 
of the recipient of the message re-expressed in the target text. In an attempt to raise awareness of these difficulties and ensure that students do not leave prepositional usage by the wayside as they are immersed in the many other challenges of interlingual translation or proofreading, it is suggested that some in-class time be spent focusing on this aspect of the language.

\section{PREPOSITIONS AND PARTICLES IN TRANSLATED DISCOURSE}

As Stern (1983) reminds us, "Language is both rule-governed and creative" (p. 184), and this is particularly true of the usage and use of prepositions and particles in English, where they sometimes appear to defy the possibility of an exhaustive description for prescriptive purposes. A case in point would be their use in the formation of prepositional and phrasal verbs. Undoubtedly, one of the aspects of prepositional and particle usage in English which non-native speakers find most taxing is that of such verbs. In her article on the creative use of phrasal verbs in scientific and technical text types, Campoy Cubillo (2012) states that "Phrasal verbs are one of the most creative resources of the English language, since new combinations are easily created by attaching particles to verbs ... and in this way they express some new concept" (p. 97). Indeed, it is precisely the versatility of their meaning in a range of different co-texts and the possibility of new coinages that enthrall native speakers of English, whereas EFL learners naturally find them most daunting. Probably the golden rule is "when in doubt, seek a valid alternative"; this advice should perhaps have been taken into account by the translator of the following piece of discourse found in an official tourist information leaflet entitled 52 semanas $y$ un destino/ 52 Weeks and a Destination:

\begin{abstract}
Este folleto ha sido realizado por... Se han consensuado sus características y contenido en distintas reuniones de trabajo... El fin último que hemos perseguido es el de proporcionar una herramienta que no sólo tenga una utilidad turística y promocional, sino también...
\end{abstract}

\author{
This leaflet has been made [sic] by ... The \\ Group has agreed [sic] its structure and \\ aims within the different working group \\ meetings ... The final aim is to provide a tool \\ that goes over [sic] its usefulness in terms \\ of tourism and promotional purposes but \\ also it [sic] contributes ...
}

Although other errors could be mentioned, in this case, our concern is the misuse of the phrasal verb "go over"; it clearly does not transmit the meaning of the discourse printed in the original Spanish version "no sólo... sino también," used for addition and emphasis. It is likely that the Spanish translator meant "to go beyond its usefulness"; in other words, to transmit the notion of "va más allá de."

This is precisely the type of problem Bassnett (2014) refers to in her book Translation when she says: "Students of English quickly encounter what I call 'the killer preposition,' that is, the English usage of prepositions to completely alter the meaning of a verb" (p. 59). Nonetheless, it is beyond the scope of this article to fully delve into the topic of prepositional and phrasal verbs or phrasal nouns; 
it is the rendering of prepositions, these closed-class items, in prepositional phrases encountered in translated or proofread discourse in English that is the main concern here.

The proficient translator should always ensure a complete understanding of the source text before embarking upon its translation; a failure to do so is undoubtedly a cause for serious error. In today's internet era, students are often tempted to think that the answer to virtually everything is there, on the internet, pre-packed and ready to use with relative ease yet, as Hurtado Albir (2007) puts it,

La comprensión del intérprete y del traductor se diferencian de la de un receptor normal, ya que para ellos es un acto deliberado de comprensión, siendo más analítica y ha de perseguir la captación del sentido íntegramente, de modo que éste se adecue al querer decir del emisor del texto original (p. 323).

When dealing with the interpretation of prepositions and particles in a variety of structures, a mixture of both a knowledge of their usage and a feeling for their use is essential in the corresponding analysis if the often important and interesting nuances which they express in combination with other linguistic elements are not to be forfeited. The principal aim of this article is to underline this notion and contribute samples of prepositional and particle usage in translation as well as relevant observations for promoting the in-class development of an awareness of the problems encountered in this area with regard to the comprehension of source text messages and their subsequent re-expression. This study proposes activities based on the analysis of prepositions and particles in translated written communicative events where Spanish and English are used. Some examples, taken from real data, have been selected: from texts translated or directly produced by undergraduate and postgraduate translator trainees, by organisations, or by specialists from diverse fields.

As previously mentioned, minor errors producing mere oddity but not a distortion of the original message are not the main consideration in this paper. Instead, the focus has been on incorrect usage in academic articles and translated texts conducive to a degree of misinformation and confusion. Needless to say, the samples presented in class for analysis are not decontextualised but embedded in chunks of discourse, in groups of words, in units of meaning, and students are provided with information about the context of situation. However, for the purposes of this article, these samples have been reduced, hopefully leaving the reader with sufficient discourse and co-text with which to reflect on the type of recurrent problem being referred to.

All too often, from the point of view of translator trainees, the status of prepositions and particles at information level is seemingly humble, yet this is not always applicable. Furthermore, the establishment of false equivalents by students can make these linguistic elements seem relatively uncomplicated and, as a consequence, they do not always receive the attention they require. A typical case is the translation into English of the very versatile Spanish preposition "de": as a decontextualised item it could be rendered as, for example, "of," "from," "about," or "in." Nevertheless, there is a tendency amongst Spanish-speaking students to mistakenly determine that English "of" is an equivalent of "de", seeing it as valid for virtually all co-texts. Only careful analysis of the source text meaning will enable the translator to decide on the most appropriate rendering of the contextualised preposition in the target text; this may entail the use of a noun as premodifier in the English version in order to 
express the meaning of the prepositional phrase with "de" in Spanish. Consider the following samples collected from the homework of Spanish-speaking students during a final-year undergraduate inverse translation course; the texts used are related to the tourism sector and in their translation a common mistransfer of "de" was generally detected (see Table 1).

\section{Table 1}

Example taken from a menu supplied at a restaurant in South-East Spain

\begin{tabular}{|l|l|l|}
\hline Source Text & Mistranslations & Author's Proposal \\
\hline $\begin{array}{l}\text { Tortillita de } \\
\text { camarones }\end{array}$ & $\begin{array}{l}\text { Tortilla with shrimp (found in a restaurant's English version } \\
\text { and in the work of final-year undergraduate trainees) }\end{array}$ & Shrimp fritters \\
\hline $\begin{array}{l}\text { Omelette of shrimp (found in the work of final-year } \\
\text { undergraduate trainees) }\end{array}$ & \\
& $\begin{array}{l}\text { Omelette with shrimp (found in the work of final-year } \\
\text { undergraduate trainees) }\end{array}$ & \\
\hline
\end{tabular}

This fragment has been taken from a bilingual Spanish-English menu supplied at a restaurant in South-East Spain, where many English-speaking people not only spend their holidays but also now live. Interestingly for students, the restaurant's mistransfer involving "with" implies that the dish is served with some shrimp on the side, whereas the original text indicates that the shrimps are the filling. The same problems of interpretation and transfer arise in the translation of Croquetas de Roquefort $y$ nueces and Croquetas de jamón ibérico, which some students rendered as Croquettes with Roquefort Cheese and Walnuts and Croquettes with Iberian Ham, respectively.

Let us study another sample. On this occasion, the discourse text type is an article published in an airline magazine, ling: Here, There \& Everywhere (June, 2016), about a café in the Ibizan village of Santa Gertrudis; delicious sandwiches are served there (see Table 2).

\section{Table 2}

Example taken from an airline magazine

\begin{tabular}{l|l|l}
$\begin{array}{l}\text { Source Text } \\
\begin{array}{l}\text { Mistranslation found in the work of } \\
\text { final-year undergraduate trainees }\end{array}\end{array}$ & $\begin{array}{l}\text { Author's Proposal and } \\
\text { Translator's Proposal }\end{array}$ \\
$\begin{array}{l}\text { En Santa Gertrudis hay un templo } \\
\text { del bocata, el Bar Costa, donde } \\
\text { Vincent hace unos llonguets planos }\end{array}$ & a temple of the sandwich/sandwiches & $\begin{array}{l}\text { In Santa Gertrudis there's a temple } \\
\text { to the crusty bap, Bar Costa, where }\end{array}$ \\
que sirve con rellenos sencillos & & $\begin{array}{l}\text { Vincent makes flat llonguets } \\
\text { served with straightforward fillings }\end{array}$
\end{tabular}


In most cases, students rendered un templo del bocata as a temple of the sandwich/sandwiches because they failed to realise that, although it is true that in English "of" is used in collocations of the type, "the Temple of Zeus" or "the Temple of the Virgin Mary," in reference to a sandwich or bap, this would sound far too rhetorical. In the version published in English, the same piece was translated as follows: "In Santa Gertrudis there's a temple to the crusty bap ...". The intended message in the original version has successfully been conveyed by the translator since the prepositional phrase to the crusty bap implicitly means "dedicated to the crusty bap." Curiously, were the translation with "of", as provided by numerous students, rewritten with capitalisation and inverted commas as "The Temple of the Sandwich/Bap," a new and humorous nuance, not present in the source text, would be added.

So far, several examples of the Spanish preposition "de" have been explored, but a similar degree of complexity is experienced when translating the preposition "en" from Spanish into English: as a decontextualised item, it is regularly rendered as "at," "in," or "on," but this could again be considered a somewhat rash oversimplification as the examples below will show:

Te presentamos unas vacaciones diferentes, alternativas, en la naturaleza y en el mar...Vivirás la sensación de cenar en el mar y de ver las estrellas.

This extract can be found on a web page (http://www.cetaceosynavegacion.com/) offering whalewatching boat trips. In both cases in which en el mar is used in Spanish, students generally opted for in the sea and on the sea. The best rendition for the first instances of "en" could be in natural surroundings, at sea, where two different prepositions would be used in English. In contrast, dine on board as a translation of cenar en el mar is a reformulation easily found in parallel texts of this kind in English. The following is another example with the preposition "en" (see Table 3).

Table 3

Example taken from a tourist brochure

\begin{tabular}{|c|c|c|}
\hline Source Text & $\begin{array}{l}\text { Mistranslation found in the } \\
\text { Tourist Office's English version }\end{array}$ & Author's Proposal \\
\hline $\begin{array}{l}\text { Soñar en Los Alcázares } \\
\text { la heading for a paragraph } \\
\text { about what the resort of } \\
\text { “Los Alcázares” offers) }\end{array}$ & Dream with Los Alcázares & $\begin{array}{l}\text { 1. Dreaming about Los Alcázares (with } \\
\text { reference to being there in the future) } \\
\text { 2. Dreaming in Los Alcázares (while there, you } \\
\text { can relax, enjoy yourself and make plans) }\end{array}$ \\
\hline
\end{tabular}

This negative instance, found in a tourist brochure with information about a popular seaside resort, "Los Alcázares," is based on a double error: first, the Spanish preposition "con" is regularly used with the verb "soñar" to mean "to dream about/of" and the translator seems to have wrongly decided that "con" is an equivalent of "with" when used to express a prepositional complement, probably because both prepositions are used in a similar manner in English and Spanish to refer 
to spatial relationships. Furthermore, "en" and not "con" is used in the original Spanish version, and this lends the sentence two different interpretations which equally complement the ensuing discourse. Hence, here the translator is faced with a choice; this is, in Pym's words, "the selective moment of translating, when decisions have to be made between the available alternatives" (2010, p. 5). The translator's choice of the English imperative "Dream" has been softened in the author's proposals with the use of a present participle thereby transmitting the notion that the visitor actively participates in the construction of the ideal advertised.

Turning our attention to the present-day global world of business and finance, written texts sent to and from international companies frequently serve as calling cards, in the sense that through them the efficiency and savoir-faire of their physically absent senders can be transmitted. In this regard, Hurtado Albir (2007) emphasises that:

Al producirse con el medio escrito, el traductor requiere una destreza de comprensión lectora en la lengua de partida y de producción escrita en la lengua de llegada; de ahí que el traductor tenga que ser un buen lector y un excelente redactor (p. 74).

Translating and proofreading discourse of this nature are therefore tasks which involve a considerable degree of responsibility and, once more, taking the time and care to choose what is correct and most appropriate in a particular context is all part and parcel of ensuring that a client's message is adequately communicated. With respect to prepositional usage, below are more examples for inclass analysis and pair or group debate taken from several Spanish-English business correspondence translations submitted during a Master's Course in Business and Finance Translation at the University of Salamanca. The average level in English of the attending students was C1-C2 of the CEFR and one of the outstanding features of their individual interlanguage profiles was recurrent difficulty in the use of prepositions and particles in diverse contexts (see Table 4).

Table 4

Examples taken from several Spanish-English business correspondence texts

\begin{tabular}{|c|c|c|}
\hline Source Text & Mistranslation & Author's Proposal \\
\hline $\begin{array}{l}\text {-Actualmente carecemos de } \\
\text { representación en Gran Bretaña. }\end{array}$ & $\begin{array}{l}\text {-We are currently lacking of } \\
\text { representation in the UK }\end{array}$ & $\begin{array}{l}\text {-We are currently lacking } \\
\text { representation in the UK }\end{array}$ \\
\hline $\begin{array}{l}\text {-Se le asignará la comisión de cualquier } \\
\text { pedido que se reciba de Gran Bretaña }\end{array}$ & $\begin{array}{l}\text {-You will receive the commission of } \\
\text { any order received of the UK. }\end{array}$ & $\begin{array}{l}\text {-You will receive the commission } \\
\text { for any order from the UK }\end{array}$ \\
\hline $\begin{array}{l}\text {-Rogamos se sustituya el adhesivo C1 } \\
\text { TE por el C2TES2 Flex }\end{array}$ & $\begin{array}{l}\text {-We would appreciate if you could } \\
\text { substitute adhesive C1 TE for } \\
\text { C2TES2 Flex }\end{array}$ & $\begin{array}{l}\text {-We would appreciate it if } \\
\text { you could substitute adhesive } \\
\text { C2TES2 Flex for C1 TE } \\
\text { - We would appreciate it if you } \\
\text { could substitute adhesive C1 TE } \\
\text { by/with C2TES2 Flex }\end{array}$ \\
\hline
\end{tabular}


While the errors in the first two examples do not impede adequate communication of the main message, this is not the case in the third sample where the meaning has been changed because students were influenced by the Spanish syntax of the original. This can be seen very clearly in these examples for the first definition for "sustituir" in the $6^{\text {th }}$ edition of the Collins Diccionario españolinglés, English-Spanish: "sustituir A por B" rendered as "to replace $A$ by/ with $B$, substitute $B$ for $A$ ". The following example for the verb "to substitute" taken from the New Oxford Dictionary of English and the author's subsequent rephrasing will illustrate the difference in meaning due to prepositions and word order:

Dried rosemary can be substituted for the fresh herb (El romero natural se puede sustituir por el romero secol.

The fresh herb can be substituted by/with dried rosemary (El romero seco puede sustituir al romero naturall.

In other words, dried rosemary can be used as a substitute for the fresh herb.

With reference to scientific translation (from Spanish into English), it is generally acknowledged that it tends to be more linear in comparison with the translation of other text types, e.g. literary translation; however, from a grammatical perspective, the order of adjectives before nouns, the use of noun modifiers, and the re-expression of prepositional structures require great precision. Regarding prepositions and particles, negative transfers, and therefore misrepresentations, in this area of grammar may, unfortunately, result in faulty descriptions of research processes and trials. In Table 5, the first example, taken from the catalogue of a company that prepares kits for clinical trials and research assays, together with the explanation in the next paragraph, will help illustrate this to students:

\section{Table 5}

Examples taken from the catalogue of a company that prepares kits for clinical trials and research assays

\author{
Source Text \\ -Servicio: Desarrollo de ensayo \\ espectrofotométrico de actividad \\ enzimática. \\ - La incubación del anticuerpo \\ con las células sin seguir los \\ procedimientos recomendados \\ puede concluir con una \\ disminución o pérdida de los \\ determinantes antigénicos de la \\ superficie celular.
}

Mistranslation

-Service: Development of a spectrophotometric assay of/for enzymatic activity.

-The incubation of the antibody with the cells without following the procedures recommended can conclude in a reduction or loss of the antigenic determinants of the surface of the cell.

\section{Author's Proposal}

Service: Development of a spectrophotometric assay of/for enzymatic activity.

\footnotetext{
- If the procedures recommended for antibody and cell incubation are not followed, this can result in a decrease or loss of cell surface antigenic determinants.
} 
Final-year translation trainees were given several pages of text to translate as homework. When dealing with the discourse in the first example, some chose "of enzymatic activity" while others selected "for enzymatic activity." Both renditions are feasible. Nonetheless, the translation depends on whether the enzymatic activity has already taken place or not. In the second example, from the same source, by using "of" students expressed the meaning required, but the discourse in English sounds unnatural. With the help of parallel texts, students were able to reach the conclusion that the English version could be improved by using some nouns as premodifiers as an alternative to prepositional phrases with "of." Thus, the discourse generated in class reads: "If the procedures recommended for antibody and cell incubation are not followed, this can result in a decrease or loss of cell-surface antigenic determinants".

When studying prepositional and particle usage, it is also wise to remind trainees that in nativespeaker discourse, both spoken and, particularly, written, preference for one preposition over another may not always be due merely to meaning: register and tone may well come into play, too. Consider the following sample from a still-to-be-published medical article recently proofread by the author, where, from a pragmatic point of view, the change from "about" to "of" is more appropriate because it gives a decidedly more formal and professional ring to the discourse. Also, as can be seen, other changes have been made in word order and vocabulary and the uncountable noun "knowledge" has been corrected.

\section{Original version}

In addition, some of the participants in the included clinical trials were interviewed in order to learn their knowledges about the investigated issues.

\section{Author's Proposal \\ In addition, some of the participants in the clinical trials included (in the study) were interviewed in order to verify their knowledge of the issues under research.}

The complexity of prepositional and particle usage and the types of pitfalls resulting from incorrect choices have been illustrated above with samples embedded in their authentic contexts and co-texts. Nonetheless, given that students tend to overgeneralise when approaching this area of grammar, one of the main challenges faced by TS and EFL teachers, in general, is the need to make learners conscious of the multiplicity of functions that prepositions and particles fulfil, e.g., in the expression of time/spatial relationships; as linking elements with verbs which require a prepositional complement; in combination with verbs and nouns in the formation of numerous idiomatic expressions, or as an essential element in the formation of some linking and conjunctive expressions, for example, in spite of, in addition to, which belong to a group of valuable cohesive or unifying devices. In this regard, as Nunan (1993) says:

Much of the research into the ability of pupils to understand written discourse has focused on the area of conjunction ... the ability to comprehend these relationships is an important skill for those who need to read academic texts .... The perception of logical connectives is an important factor in success in reading science texts at the secondary level (p. 110). 
In this sense, it is important for the trainee to understand that, across this wide spectrum of syntactical structures and discoursal contexts, each preposition or particle may be used very differently, and there is more often than not no rationale which allows the future translator to make valid assumptions regarding the use of a given preposition in a complete range of grammatical and lexical structures. In his article, “Five Uses for Grammar in Foreign Language Teaching," James (1989) asserts:

Perhaps $90 \%$ of $\mathrm{FL}$ learners in schools have no social motivation for learning the FL: only instrumental ones .... The other 10\%-call them an élite if you like-will be the future teachers, diplomats, and translators: for this group attention to grammar is inevitable because their professional commitments call for what is tantamount to linguistic naturalization (p. 117).

It is indeed essential that translator trainees acquire an in-depth knowledge of the linguistic structures and forms both of their mother tongue and their foreign languages, as well as the discourse skills required for the production of coherent and cohesive communication. Only by means of abundant input, observation, analysis, explanation, debate, and practice will students develop an adequate knowledge of "the language as a formal system with rules and regular relationships between language forms and meanings" (Stern,1983, p. 411). In this regard, it is also advisable to remind students at tactical intervals of their own vital role in their individual learning process, where the teacher or lecturer is an essential guide, but where the students' capacity for creating language immersion strategies and taking the time and initiative to fathom the true meaning of source texts for their careful re-expression is a fundamental element in the development of their translation competence. As Kelly (2005) reminds us:

There has been a recent move in European higher education, and also in other parts of the world, toward a new model of tertiary education, where the key elements are clear definition of aims and intended outcomes and more student-centred learning (p. 33).

This shift of focus at the university level is intended to encourage students to increase their strategic competence, become less teacher-dependent and function independently in preparation for their future professional situation and as a basis for continuing their own life-long learning programme. In the case of translation trainees, this could clearly be aided by their making adequate use of diverse tools, such as dictionaries and corpora (Gallego-Hernández, 2015; Rodríguez-Inés 2014), as translation resources. Moreover, a variety of collaborative learning activities based on inductive reasoning stimulated by thought-provoking questions from the teacher and from students about the meanings of different combinations of linguistic forms provided as translations can be implemented in the classroom. Such activities can be carried out in pairs, in syndicates, in buzz groups or, in order to foment students' interaction with different sets of classmates, cross-over groups; the overall objective being to allow trainees to pool ideas and share proposals and common problems before attempting this at the, for some, more intimidating whole-class level.

Ideally, texts for study in and out of class should be selected from diverse genres, and the full spectrum of tone and style should be covered. As an alternative to the standard exercise of translating a source text directly into a target text, paired or grouped students could be provided with authentic target 
texts with their genuine flaws, such as those to be found in the samples included in this article, for exploration and discussion about those errors which impede communication of the original message and those which decrease text quality or do not comply with register and tone norms. To ensure that there is diversity in classroom activities so as to maintain interest and motivation, trainees could also be asked to read a source text, with relevant information about the context of situation, and then study an authentic translation containing strategic gaps where, in this case, prepositional phrases and verbs with particles have been removed. This activity would end with a debate about the best options offered and an evaluation of the corresponding renditions in the published translation. Alternatively, the same procedure could be followed, but with multiple choice options instead of blanks; the latter kind of exercise usually gives rise to a greater level of discussion. For the purposes of these in-class holistic analyses of samples, long pieces of contextualised discourse should be presented to students for their perusal and, to this end, it is also worth requesting trainees to bring in their own doubts and enquiries, illustrated with relevant samples of their choice taken from authentic materials, for exploration and debate in class.

Finally, with a view to correcting serious and persistent errors in usage through explicit grammar instruction, it is also recommended that further remedial work be done, based on a complementary atomistic approach with refresher structural exercises, whether in the form of gap-filling tasks, rephrasing of structures, or sentence completion, to be carried out by trainees on their own and for self-correction via the subject's web page, with any worries or doubts raised in the classroom or in tutorials.

\section{CONCLUSION}

Once students have become aware of the challenges involved in the correct rendering of prepositions and particles in discoursal use and the importance of this in effective communication, it is much easier for the instructor to aid them in paying greater attention to features of the kind discussed in this article. It has been argued here that highlighting the need for linguistic accuracy is not incompatible with the theory that in the act of translation it is imperative to transmit the meanings and messages of the original unit of meaning, the source text. According to Halliday and Hasan (1976), "A text is best regarded as a semantic unit: a unit not of form but of meaning" (p. 2).

To take a very clear example of what is meant by this, in the translation of discourse produced for the purpose of advertising, not only is it vital to capture the meaning of the original version, but in the corresponding translation it is also fundamental to maintain the impact of the advertiser's message on the target text recipients, transmitting puns, jingles, alliteration, and any additional elements. The resultant version may well have radical changes in its syntactical form with respect to the original message; however, if its meaning and essence are kept, and the target text is sufficiently accurate in itself, the translation will certainly be satisfactory.

Without wishing to make trainees feel lost in a sea of information, teachers could judiciously remind them that, depending on a client's requirements, it may be necessary to offer a "localised" translation of the source text and that this may affect the choice of features such as prepositions and 
particles. By way of example, we might mention that between American and British English there are differences in use in some idiomatic expressions such as to fill out a form (American) and to fill in a form (British); in grammatical collocations such as Monday through Friday (American) and Monday to Friday (British); as well as in cases such as to meet with someone, to write someone (American) and to meet someone, to write to someone (British).

The conscientious translator trainee should, therefore, always have preposition and particle use and usage on his or her checklist for reviewing work before it is submitted. Techniques such as back translation can be used individually and in the classroom as a method of double-checking for meaning but inevitably, where it all starts, is with a careful and analytical reading of the source text and an assurance of its full comprehension and transmission.

As we are reminded in an article published on the web page of the Translation Centre for the Bodies of the European Union, "It should be remembered that mistakes can occur not only in the meaning conveyed by words, but are often hidden in details: an incorrect preposition, tense, word order, or even a comma can change the meaning of the whole sentence" (Mall, n.d., "The Art of Revision").

\section{REFERENCES}

Bassnett, S. (2014). Translation. Abingdon/New York: Routledge.

Beeby, A. (1996). Teaching Translation from Spanish to English. Ottawa: University of Ottawa Press.

Campoy Cubillo, Ma . C. (2012). Phrasal and Prepositional Verbs in Specialised Texts: A Creative Device. Ibérica, 4, 95-111. Retrieved from http:// www.aelfe.org/documents/text4-Campoy.pdf

Cook, G. (1989). Discourse. Oxford: OUP.

Corder, P. S. (1973). Introducing Applied Linguistics. Middlesex: Penguin Books.

Gallego-Hernández, D. (2015). The use of corpora as translation resources. A study based on a survey of Spanish professional translators. Perspectives: Studies in Translatology, 23(3), 375-391. doi: http://dx.doi.org/10.1080/0907676X.2014.964269

Halliday M. A. K. \& Hasan R. (1976). Cohesion in English. London: Longman.

Hurtado Albir, A. (2007). Traducción y traductología (3a ed.). Madrid: Cátedra.

James, C. (1989). Five Uses for Grammar in Foreign Language Teaching. In R. Álvarez Rodríguez \& R. López Ortega (Eds.), Communication Theory and Language Teaching Practice (pp. 107-121). Salamanca: Ediciones Universidad de Salamanca.

Kelly, D. (2005). A Handbook for Translator Trainers. Manchester: St. Jerome Publishing.

Liming Y., \& Odlin, T. (Eds.) (2015). New Perspectives on Transfer in Second Language Learning. Bristol: Multilingual Matters.

Mall L. (n.d.). The Art of Revision, Translation Centre for the Bodies of the European Union. Retrieved from http://cdt.europa.eu/ES/whatwedo/ Pages/Translation-annexes/The-art-of-revision.aspx

Nunan, D. (1993). Introducing Discourse Analysis. London: Penguin.

Odlin, T. (2010). Language Transfer. Cross-Linguistic Influence in Language Learning. Cambridge: CUP.

Pym, A. (2010). Exploring Translation Theories. Abingdon/New York: Routledge. 
Rodríguez-Inés, P. (2014). Using Corpora for Awareness-raising Purposes in Translation, Especially into a Foreign Language (Spanish-English). Perspectives: Studies in Translatology, 22(2), 222-241. doi: http://dx.doi.org/10.1080/0907676X.2012.685239

Selinker, L. (1972). Interlanguage. International Review of Applied Linguistics in Language Teaching, 10(1-4), 209-232. doi: https://doi.org/10.1515/ iral.1972.10.1-4.209

Stern, H. H. (1983). Fundamental Concepts of Language Teaching. Oxford: OUP.

Swan, M. (1995). Practical English Usage (2 ${ }^{\text {nd }}$ ed.). Oxford: OUP.

Widdowson, H. G. (1978). Teaching Language as Communication. Oxford: OUP.

\section{AUTHOR'S NOTE:}

This article is part of a research project entitled "Violencia simbólica y traducción: retos en la representación de identidades fragmentadas en la sociedad global" [Symbolic Violence and Translation: Challenges in the Representation of Fragmented Identities within the Global Society] (FFI201566516-P; MINECO/FEDER, UE), financed by the Spanish Ministry of Economy and Competitiveness.

(c) The authors. This article is being published by the Educational Quality Department's Research Area Revista Digital de Investigación en Docencia Universitaria, Universidad Peruana de Ciencias Aplicadas (UPC). This is an open-access article, distributed under the terms of the Attribution-ShareAlike 4.0 International Creative Commons License (http://creativecommons.org/licenses/by-sa/4.0/), which allows the non-commercial use, distribution and reproduction in any media, provided the original work is properly cited. 